\title{
Surgical reconstruction of hip subluxation and dislocation in children with cerebral palsy
}

\author{
Serebral palsili çocuklarda kalça subluksasyonu ve dislokasyonunun cerrahi rekonstrüksiyonu
}

\author{
Murat Oto, MD, ${ }^{1}$ Ilker Abdullah Sarıkaya, MD, ${ }^{2}$ Ozan Ali Erdal, MD, ${ }^{2}$ Ali Şeker, MD ${ }^{3}$ \\ 'Department of Orthopedics and Traumatology, Medical Faculty of Pamukkale University, Denizli, Turkey \\ ${ }^{2}$ Ortopediatri Pediatric Orthopaedics Academy, İstanbul, Turkey \\ ${ }^{3}$ Department of Orthopedics and Traumatology, İstanbul Medipol University, İstanbul, Turkey
}

\begin{abstract}
Objectives: This study aims to review the efficacy of femoral varus derotation osteotomy (VDRO) and Dega transiliac osteotomy in the treatment of hip subluxation and dislocation of cerebral palsy $(\mathrm{CP})$ patients.

Patients and methods: This retrospective study included 25 hips of $22 \mathrm{CP}$ patients (9 males, 13 females; mean age 8.7 years; range, 4 to 18 years) who were operated due to hip subluxation and dislocation between July 2010 and December 2015. The mean follow-up period was $36.1 \pm 10.4$ months (range, 20 to 65.6 months). Femoral VDRO and Dega transiliac osteotomy were performed in all cases. None of the patients were administered cast immobilization postoperatively. Patients were evaluated clinically with gross motor function classification system preoperatively and at the follow-up period. Acetabular index (AI), migration percentage (MP), and neck-shaft angle (NSA) were measured and documented by pelvic radiographs taken pre- and postoperatively and at the follow-up period. Intraand postoperative complications were recorded.
\end{abstract}

Results: Gross motor function classification system scores improved in 16 patients. Mean AI was $33.2^{\circ}$ preoperatively and $20.4^{\circ}$ postoperatively. In preoperative period, MP and NSA were $72.7 \%$ and $160^{\circ}$, respectively, which improved to $24.3 \%$ and $130^{\circ}$, respectively, postoperatively. The postoperative improvement in AI, NSA and MP were statistically significant $(p<0.001)$. We performed revision surgery due to implant failure in two patients and detected hip subluxation due to increased pelvic obliquity in one patient who had thoracolumbar scoliosis.

Conclusion: In CP patients, reconstruction of hip subluxation and dislocation with femoral VDRO and Dega transiliac osteotomy establish femoroacetabular congruency. Without any cast immobilization, early physical therapy is encouraged for immediate recovery.

Keywords: Cerebral palsy; femoral varus derotation osteotomy; hip dislocation; iliac osteotomy; subluxation.

\section{ÖZ}

Amaç: $\mathrm{Bu}$ çalışmada serebral palsi (SP) hastalarında kalça subluksasyonu ve dislokasyonunun tedavisinde femur varus derotasyon osteotomisi (VDRO) ve Dega transiliyak osteotomisinin etkinliği incelendi.

Hastalar ve yöntemler: Geriye dönük bu çalışmaya Temmuz 2010 - Aralık 2015 tarihleri arasında kalça subluksasyonu ve dislokasyonu nedeniyle ameliyat edilen 22 SP hastasının (9 erkek, 13 kadın; ort. yaş 8.7 yıl; dağılım $4-18$ yıl) 25 kalçası dahil edildi. Ortalama takip süresi $36.1 \pm 10.4$ ay (dağılım 20-65.6 ay) idi. Tüm olgularda femur VDRO ve Dega transiliyak osteotomisi uygulandı. Ameliyat sonrasında hastaların hiçbirine alçı ile immobilizasyon uygulanmadı. Hastalar ameliyat öncesinde ve takip süresinde kaba motor fonksiyon sınıflandırma sistemi ile klinik olarak değerlendirildi. Asetabular indeks (AI), migrasyon yüzdesi (MY) ve boyun-cisim açısı (BCA) ameliyat öncesinde, sonrasında ve takip süresinde çekilen pelvis grafileri ile ölçülüp belgelendi. Ameliyat sırası ve sonrası komplikasyonlar kaydedildi.

Bulgular: Kaba motor fonksiyon sınıflandırma sistemi skorları 16 hastada iyileşti. Ameliyat öncesi ortalama AI $33.2^{\circ}$, ameliyat sonrası $20.4^{\circ}$ idi. Ameliyat öncesi sırasiyla $\% 72.7$ ve $160^{\circ}$ olan MY ve BCA, ameliyat sonrası sırasıyla $\% 24.3$ ve $130^{\circ}$ 'ye iyileşti. Aİ, BCA ve MY'deki ameliyat sonrası iyileşme istatistiksel olarak anlamlı idi $(\mathrm{p}<0.001)$. İki hastada implant yetmezliği nedeniyle revizyon cerrahisi uygulandı ve torakolomber skolyozu olan bir hastada artmış pelvik oblisiteye bağlı kalça subluksasyonu saptand1.

Sonuç: Serebral palsi hastalarında kalça subluksasyonu ve dislokasyonunun femur VDRO ve Dega transiliyak osteotomisi ile rekonstrüksiyonu femoroasetabular uyum sağlar. Hızlı düzelme için alçı ile immobilizasyon olmaksızın erken fizyoterapi teşvik edilir.

Anahtar sözcükler: Serebral palsi; femur varus derotasyon osteotomisi; kalça dislokasyonu; iliyak osteotomisi; subluksasyon.

- Received: December 27, 2017 Accepted: February 02, 2018

- Correspondence: Murat Oto, MD. Pamukkale Üniversitesi Tıp Fakültesi, Ortopedi ve Travmatoloji Anabilim Dalı, 20070 Kınıklı, Denizli, Turkey. Tel: +90 0532 - 4271343 e-mail: muratoto@hotmail.com 
Hip dislocation may lead to pain, poor sitting balance, and difficulty with perineal care in children with cerebral palsy $(\mathrm{CP}) .^{[1-3]}$ Overactive hip adductors and flexors, increased femoral neckshaft angle (coxa valga) and acetabular dysplasia are major pathological causes. ${ }^{[4-6]}$ Treatment options include physical therapy, botulinum toxin injection, soft tissue release, proximal femoral varization, femoral varus derotation osteotomy (VDRO) and acetabular/transiliac osteotomy. ${ }^{[7-11]}$ In this study, we aimed to review the efficacy of femoral VDRO and Dega transiliac osteotomy in the treatment of hip subluxation and dislocation of CP patients. ${ }^{[12]}$

\section{PATIENTS AND METHODS}

This multicenter retrospective study included 25 hips of $22 \mathrm{CP}$ patients (9 males, 13 females; mean age 8.7 years; range 4 to 18 years) who were operated due to hip subluxation and dislocation between July 2010 and December 2015. The inclusion criteria were a primary diagnosis of $\mathrm{CP}$ with hip subluxation or dislocation graded as 3 or 4 according to the Tönnis classification and being older than four years of age. ${ }^{[13]}$ Three patients were operated bilaterally and 19 patients unilaterally. Mean follow-up was $36.1 \pm 10.4$ months (range 20 to 65.6 months). The study protocol was approved by the Medipol University Ethics Committee. A written informed consent was obtained from each patient. The study was conducted in accordance with the principles of the Declaration of Helsinki.

Patients were evaluated with gross motor function classification system (GMFCS) pre- and postoperatively. Anteroposterior pelvic radiographies

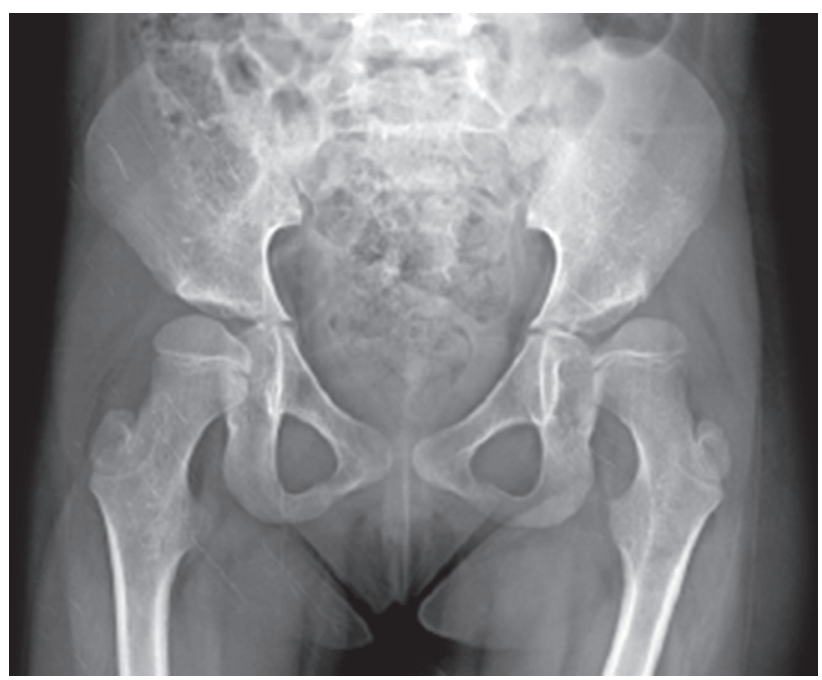

Figure 1. Preoperative radiograph. were taken preoperatively (Figure 1), immediately postoperatively (Figure 2) every three weeks until bone healing was complete, and then once every three months till the last follow-up visit (Figure 3). We also evaluated changes in the acetabular index (AI), migration percentage (MP), and neck-shaft angle (NSA) pre- and postoperatively, and at last follow-up.

All patients were treated with femoral VDRO with Dega transiliac osteotomy as part of single event multilevel surgery. Femoral VDRO was performed at the level of lesser trochanter. All osteotomies

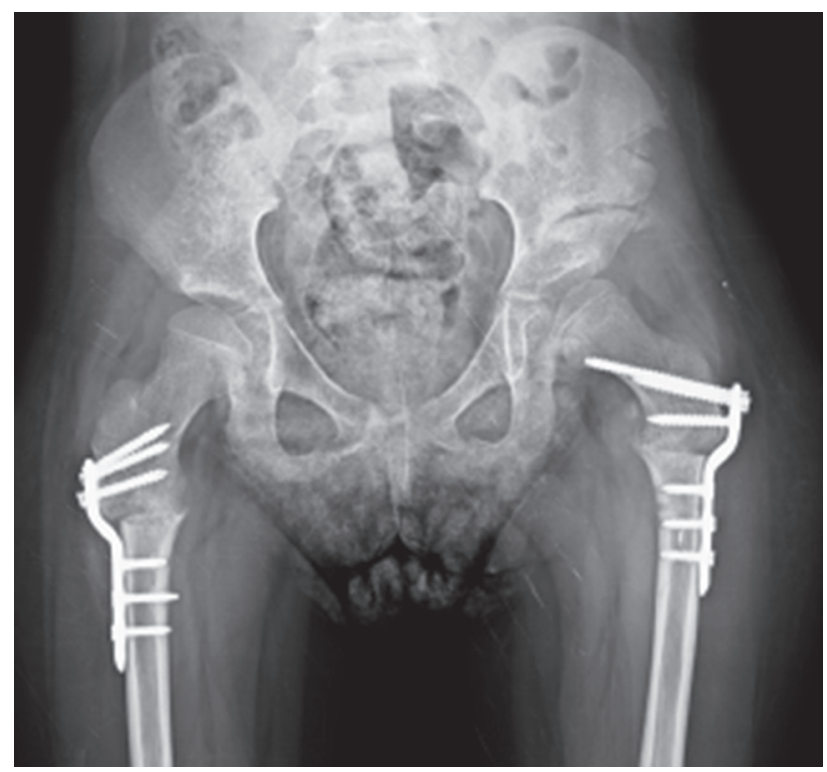

Figure 2. Postoperative radiograph of a patient after bilateral femoral varus derotation osteotomy and Dega transiliac osteotomy.

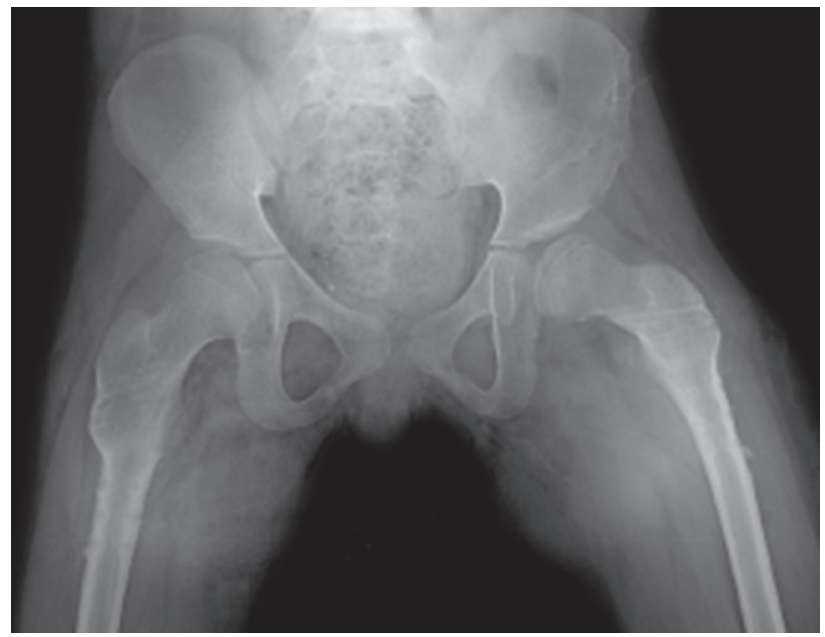

Figure 3. Follow-up radiograph of a patient after bilateral femoral varus derotation osteotomy and Dega transiliac osteotomy. 


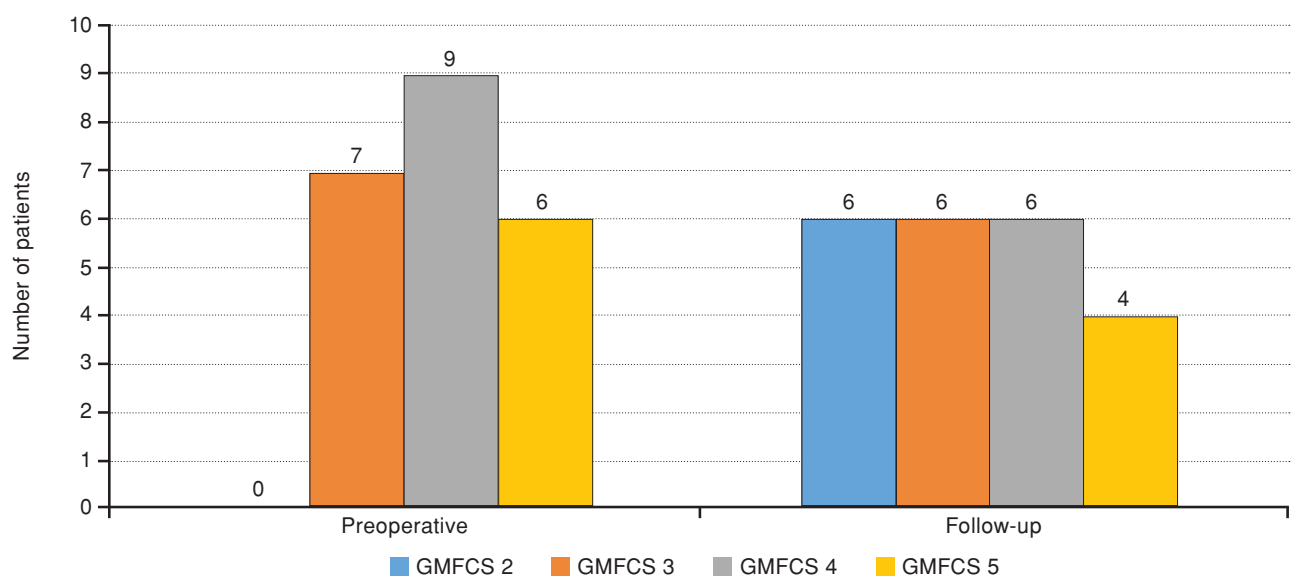

Figure 4. Preoperative and follow-up gross motor function classification system levels. GMFCS: Gross motor function classification system.

included lesser trochanter removal and shortening up to $2 \mathrm{~cm}$. Following osteotomy, the proximal femur was abducted to determine if the femoral head reduced concentrically. While the reduction was inadequate in five patients, the proximal segment of the femur was abducted, and the medial joint capsule was incised longitudinally in line with the femoral neck. Medial capsulotomy was needed for reduction in five patients. After concentric reduction was achieved, the femoral osteotomy was then fixed with a locking plate (TST Trbbi Aletler San. ve Tic. Ltd. Şti, Istanbul, Turkey). Dega transiliac osteotomy was performed for acetabular dysplasia (AI $25^{\circ}$ or higher).

Passive hip exercises began on the first postoperative day. Patients were allowed full weight bearing at the postoperative third week. Wound infection, joint stiffness, implant failure, chronic hip pain, recurrent subluxation or dislocation, avascular necrosis of the femoral head, delayed union and other complications were recorded. Delayed union was defined as a failure to reach bony union by six months postoperatively.

\section{Statistical analysis}

Statistical analysis was performed with statistical package for the social sciences (SPSS) version 15.0
(SPSS Inc., Chicago, IL, USA). Data for continuous variables were reported as mean \pm standard deviation (minimum-maximum) and data for categorical variables reported frequency. The Friedman test and the Wilcoxon rank test for binary comparisons were used to compare the continuous variables at different times. The results were evaluated at a $95 \%$ confidence interval and a significance level of $\mathrm{p}<0.05$.

\section{RESULTS}

According the Tönnis classification, 19 hips were grade 3 and six hips were grade 4 . Preoperative and follow-up GMFCS levels were reported in Figure 4: two patients classified as level 5 preoperatively improved to level 4 , five patients improved from level 4 to level 3, and six patients improved from level 3 to level 2. The postoperative changes were statistically significant in all AI, MP and NSA values $(\mathrm{p}<0.001)$ (Table I).

There was no wound infection, subluxation, or dislocation during follow-up period. Additionally, we did not observe any hip joint stiffness. One patient developed hematoma in the iliac region on the first postoperative day which was treated nonoperatively. The second complication was failure of femoral osteotomy fixation in one patient. At the follow-up

TABLE I

Pre- and postoperative and follow-up radiographic parameters

\begin{tabular}{|c|c|c|c|}
\hline & Preoperative & Postoperative & Follow-up \\
\hline & Mean $\pm S D$ & Mean $\pm S D$ & Mean $\pm S D$ \\
\hline Migration percentage & $72.7 \pm 20.8$ & $24.3 \pm 13.4^{\circ}$ & $25.9 \pm 12^{\circ}$ \\
\hline Neck-shaft angle $\left(^{\circ}\right)$ & $160 \pm 11.2$ & $130.3 \pm 18.6$ & $132 \pm 17.6$ \\
\hline Acetabular index $\left(^{\circ}\right)$ & $33.2 \pm 6.2$ & $20.4 \pm 2.6$ & $21.5 \pm 2.6$ \\
\hline
\end{tabular}

SD: Standart deviation. 
period, the patient complained about persistent pain at the thigh and groin. Radiographic examinations revealed no evidence of union, and we observed movement at the osteotomy site under fluoroscopic control, which was considered as instability. We considered inadequate stability as the reason for the persistent pain and delayed union and performed a revision of the plate fixation. Also, in one patient, implant failure due to a fall during physical therapy on the tenth postoperative day was treated by open reduction and internal fixation.

\section{DISCUSSION}

Hip subluxation and dislocation are serious health problems for $\mathrm{CP}$, particularly in nonambulatory quadriplegic patients. ${ }^{[3,14,15]}$ Pain, poor sitting balance and difficulty in perineal care are among the major problems in these patients. ${ }^{[16]}$ Treatment options include physical therapy, botulinum toxin injection, soft tissue release, open reduction, proximal femoral derotation and varization osteotomy and acetabular/ transiliac osteotomy, and total hip arthroplasty. ${ }^{[0,10,17-22]}$ We claimed that concentric reduction was achieved after treatment of hip subluxation and dislocation and acetabular dysplasia with femoral VDRO and Dega transiliac osteotomy. Additionally, we detected that successful clinical and radiological results were not impaired after thirty months of follow-up.

The goal of many surgeons in the treatment of hip subluxation and dislocation in $\mathrm{CP}$ is open reduction (excision of the ligamentum teres, transvers ligament, and pulvinar [if present] and performing a capsulorrhaphy), as in the case of developmental dysplasia of the hip (DDH) ${ }^{[1,2,19,20]}$ However, some authors have claimed that open reduction affects the stability of hip joints in $\mathrm{CP}$ patients negatively and should not be performed in $\mathrm{CP}$ patients..$^{[9,21,22]}$ Moreover, we believe that the pathology in $\mathrm{DDH}$ originates from structures that prevent intra-articular reduction, whereas the treatment of $\mathrm{CP}$ can be performed by extra-articular methods without the need for open reduction, since the pathology originates from extra-articular structures. ${ }^{[8,9,23-32]}$

Cast immobilization after recent hip joint reconstruction has become an important debate issue due to various complications. Some authors suggest routine use of spica cast after surgical hip reconstruction procedure in $\mathrm{CP}$ to achieve stability and prevent early dislocation. ${ }^{[6,27]}$ However, we believe that postoperative immobilization of the hip joint may cause avascular necrosis of the femoral head, joint stiffness, decubitus ulcers, heterotopic ossification, and pain, particularly in $\mathrm{CP}$ patients; therefore, we did not perform postoperative immobilization. As a result, we achieved sufficient femoroacetabular congruency and joint stability postoperatively and avoided such complications at the follow-up.

In the literature, recurrence rates of hip reconstruction procedures in children with $\mathrm{CP}$ were reported up to $23 \%$ despite the successful early radiological results. ${ }^{[2,24,28]}$ Mallet et al. ${ }^{[26]}$ reported that the recurrence of coxa valga deformities was the most important factor leading to recurrence. In our study, we observed only one dislocation and increased pelvic obliquity due to thoracolumbar scoliosis. We suggest that early physical therapy and weight bearing provide early return to preoperative functional status and play an important role in decreasing hip subluxation or dislocation recurrence rate.

This study has limitations, including its retrospective design and the limited number of patients included. However, it is known that the need for derotational osteotomy alone in $\mathrm{CP}$ is an infrequent situation. Another weakness of the study is that the follow-up period was short, particularly given that this type of clinical outcome might deteriorate over the long-term. Thus, further studies that report longterm results are recommended.

In conclusion, our experience with one-stage reconstruction of hip subluxation or dislocation consisting of femoral VDRO and Dega transiliac osteotomy without open reduction of hip or postoperative cast immobilization in $\mathrm{CP}$ patients revealed favorable results.

\section{Declaration of conflicting interests}

The authors declared no conflicts of interest with respect to the authorship and/or publication of this article.

\section{Funding}

The authors received no financial support for the research and/or authorship of this article.

\section{REFERENCES}

1. Canavese F, Emara K, Sembrano JN, Bialik V, Aiona MD, Sussman MD. GMFCS level III to V patients with unilateral hip involvement. Follow-up at skeletal maturity. Varus derotation osteotomy for the treatment of hip subluxation and dislocation in J Pediatr Orthop 2010;30:357-64.

2. Sankar WN, Spiegel DA, Gregg JR, Sennett BJ. Long-term follow-up after one-stage reconstruction of dislocated hips in patients with cerebral palsy. J Pediatr Orthop 2006;26:1-7.

3. Roye DP Jr, Chorney GS, Deutsch LE, Mahon JH. Femoral varus and acetabular osteotomies in cerebral palsy. Orthopedics 1990;13:1239-43. 
4. Masłoń A, Jóźwiak M, Pawlak M, Modrzewski T, Grzegorzewski A. Hip joint pain in spastic dislocation: aetiological aspects. Dev Med Child Neurol 2011;53:1019-23.

5. Al-Ghadir M, Masquijo JJ, Guerra LA, Willis B. Combined femoral and pelvic osteotomies versus femoral osteotomy alone in the treatment of hip dysplasia in children with cerebral palsy. J Pediatr Orthop 2009;29:779-83.

6. Miller F, Slomczykowski M, Cope R, Lipton GE. Computer modeling of the pathomechanics of spastic hip dislocation in children. J Pediatr Orthop 1999;19:486-92.

7. Hoffer MM. Management of the hip in cerebral palsy. J Bone Joint Surg [Am] 1986;68:629-31.

8. Pritchett JW. The untreated unstable hip in severe cerebral palsy. Clin Orthop Relat Res 1983;173:169-72.

9. Huh K, Rethlefsen SA, Wren TA, Kay RM. Surgical management of hip subluxation and dislocation in children with cerebral palsy: isolated VDRO or combined surgery? J Pediatr Orthop 2011;31:858-63.

10. Luegmair M, Vuillerot C, Cunin V, Sailhan F, Berard J. Slotted acetabular augmentation, alone or as part of a combined one-stage approach for treatment of hip dysplasia in adolescents with cerebral palsy: results and complications in 19 hips. J Pediatr Orthop 2009;29:784-91.

11. Grzegorzewski A, Jóźwiak M, Pawlak M, Modrzewski T, Buchcic P, Masłoń A. Hip joint pain in children with cerebral palsy and developmental dysplasia of the hip: why are the differences so huge? BMC Musculoskelet Disord 2014;15:96.

12. Atik OŞ. Are all case reports worth publishing? Eklem Hastalik Cerrahisi 2016;27:61.

13. Tonnis D. Nomenclature and classification of congenital hip dislocation. In: Tönnis D, editör. Congenital Dysplasia and Dislocation of the Hip in Children and Adults. 1st ed. Berlin: Springer-Verlag; 1987. p. 80-3.

14. Black BE, Hildebrand R, Sponseller PD, Griffin PP. Hip dysplasia in spastic cerebral palsy. Contemp Orthop 1994;29:101-8.

15. Boldingh EJ, Bouwhuis CB, van der Heijden-Maessen $\mathrm{HC}$, Bos CF, Lankhorst GJ. Palliative hip surgery in severe cerebral palsy: a systematic review. J Pediatr Orthop B. 2014;23:86-92.

16. Root L, Laplaza FJ, Brourman SN, Angel DH. The severely unstable hip in cerebral palsy. Treatment with open reduction, pelvic osteotomy, and femoral osteotomy with shortening. J Bone Joint Surg [Am] 1995;77:703-12.

17. Schroeder K, Hauck C, Wiedenhöfer B, Braatz F, Aldinger PR. Long-term results of hip arthroplasty in ambulatory patients with cerebral palsy. Int Orthop 2010;34:335-9.

18. Raphael BS, Dines JS, Akerman M, Root L. Long-term followup of total hip arthroplasty in patients with cerebral palsy. Clin Orthop Relat Res 2010;468:1845-54.

19. Brunner R. Which procedure gives best results in reconstructing dislocated hip joints in cerebral palsy? Acta Orthop Belg 1998;64:7-16.

20. Shea KG, Coleman SS, Carroll K, Stevens P, Van Boerum DH. Pemberton pericapsular osteotomy to treat a dysplastic hip in cerebral palsy. J Bone Joint Surg [Am] 1997;79:1342-51.

21. Connolly P, Weinstein SL. The natural history of acetabular development in developmental dysplasia of the hip. [Article in Turkish] Acta Orthop Traumatol Turc 2007;41:1-5.

22. Sherk HH, Pasquariello PD, Doherty J. Hip dislocation in cerebral palsy: selection for treatment. Dev Med Child Neurol 1983;25:738-46.

23. Eberhardt O, Wirth T, Fernandez FF. Arthroscopic reduction and acetabuloplasty for the treatment of dislocated hips in children of walking age: a preliminary report. Arch Orthop Trauma Surg 2014;134:1587-94.

24. Jóźwiak M, Marciniak W, Piontek T, Pietrzak S. Dega's transiliac osteotomy in the treatment of spastic hip subluxation and dislocation in cerebral palsy. J Pediatr Orthop B 2000;9:257-64.

25. Mubarak SJ, Valencia FG, Wenger DR. One-stage correction of the spastic dislocated hip. Use of pericapsular acetabuloplasty to improve coverage. J Bone Joint Surg [Am] 1992;74:1347-57.

26. Mallet C, Ilharreborde B, Presedo A, Khairouni A, Mazda $\mathrm{K}$, Penneçot GF. One stage hip reconstruction in children with cerebral palsy: long-term results at skeletal maturity. J Child Orthop 2014;8:221-8.

27. Ruzbarsky JJ, Beck NA, Baldwin KD, Sankar WN, Flynn JM, Spiegel DA. Risk factors and complications in hip reconstruction for nonambulatory patients with cerebral palsy. J Child Orthop 2013;7:487-500.

28. McNerney NP, Mubarak SJ, Wenger DR. One-stage correction of the dysplastic hip in cerebral palsy with the San Diego acetabuloplasty: results and complications in 104 hips. J Pediatr Orthop 2000;20:93-103.

29. Stansfield BW, Nicol AC, Paul JP, Kelly IG, Graichen F, Bergmann G. Direct comparison of calculated hip joint contact forces with those measured using instrumented implants. An evaluation of a three-dimensional mathematical model of the lower limb. J Biomech 2003;36:929-36.

30. Ito H, Song Y, Lindsey DP, Safran MR, Giori NJ. The proximal hip joint capsule and the zona orbicularis contribute to hip joint stability in distraction. J Orthop Res 2009;27:989-95.

31. Fiz N, Sánchez M, Pérez JC, Guadilla J, Delgado D, Azofra J, et al. A less-invasive technique for capsular management during hip arthroscopy for femoroacetabular impingement. Arthrosc Tech 2014;3:439-43.

32. Wenger DR, Mubarak SJ, Henderson PC, Miyanji F. Ligamentum teres maintenance and transfer as a stabilizer in open reduction for pediatric hip dislocation: surgical technique and early clinical results. J Child Orthop 2008;2:177-85. 